\section{Optimum Seasonal Mowing Heights for Smooth Crabgrass Reduction in Tall Fescue Lawns}

\author{
Kenneth Cropper, Gregg Munshaw ${ }^{1}$, and Michael Barrett
}

AdDitional INDEX wORDs. Digitaria ischaemum, prodiamine, cultural control

SumMARY. Cultural control methods for pest management are desirable as they can reduce pesticide use resulting in reduced costs and environmental impact. Previous research has shown increased mowing heights can reduce crabgrass (Digitaria sp.) populations. However, seasonal mowing height adjustments may further decrease crabgrass populations as lower heights of cut can increase turf density during optimal growing conditions. An experiment was conducted to determine ideal mowing height combinations during summer vs. fall/spring for crabgrass reductions in a tall fescue (Festuca arundinacea) sward. A half rate of prodiamine was included as a split-plot treatment to determine if mowing height combinations could reduce the amount of pesticide required to control crabgrass. Four fall/ spring mowing heights ( $1,2,3$, and 4 inches) were combined with the same summer mowing heights such that all heights were represented in both seasons. Results indicate that seasonal mowing height variations did not provide any better reduction in crabgrass populations over only using higher heights of cut consistently throughout the year. Also, the half rate of prodiamine successfully controlled crabgrass in all mowing heights except the lowest mowing height during summer months.

S mooth crabgrass (Digitaria ischaemum) is a common summer annual weed found throughout much of the United States. Its long leaves and prostrate growth give it the potential to become a serious problem in both closely mowed areas such as greens or tees, and in higher mown areas such as home lawns. This is especially true of thin and hightrafficked areas. Typically, smooth crabgrass encroachment can be prevented, or greatly diminished, by application of a preemergent herbicide such as dithiopyr, pendimethalin, or prodiamine when there is a 24 -h period of soil temperatures greater than $10^{\circ} \mathrm{C}$ (McCarty et al., 2001). Multiple applications may provide even greater crabgrass control, as Derr (2004) reported with prodiamine.

While accurate timing of preemergent herbicides can provide excellent crabgrass control, severe infestations can still occur if the herbicides are applied after seedlings have germinated. Postemergent herbicide options such as fenoxaprop, fluazifop, and quinclorac are all labeled for crabgrass control in turf (BASF Corporation,

Department of Plant and Soil Sciences, University of Kentucky, Lexington, KY 40546-0312

${ }^{1}$ Corresponding author. E-mail: gcmunshaw@uky. edu.

doi: 10.21273/HORTTECH03588-16
2012; Bayer Environmental Science, 2011; Syngenta Crop Protection, 2014). Mesotrione, a newer active ingredient in the turfgrass industry, has postemergence activity on crabgrass that is enhanced when nitrogen is applied within $3 \mathrm{~d}$ before application (Beck et al., 2015).

Despite the existence of postemergence options, control may still not be $100 \%$ or may require multiple applications for good control (Dernoeden, 2001). The bleaching potential of mesotrione on certain desirable turf species also limits where it can be used for crabgrass control. In addition to these issues, the recent restrictions placed on monosodium methanearsonate, an effective postemergent crabgrass herbicide, shows the environmental concerns with herbicide applications (Environmental Protection Agency, 2016). Environmental issues and desire for more sustainable practices are both a growing concern turf managers face when using pesticides. One method for reducing environmental effects from chemical crabgrass control is to reduce usage rates. Dernoeden (2001) examined reduced preemergent herbicide rates over a 3-year time period and found only benefin with trifluralin and prodiamine alone still provided acceptable control in the 3rd year, among the various herbicides tested. This indicated reducing application rates of several preemergence herbicides may not be appropriate for controlling crabgrass.

In addition to reducing current chemical rates, other studies have been conducted examining natural crabgrass control methods. McDade and Christians (2001) examined humic acid and soybean oil to improve the efficacy of corn gluten hydrolysate, which has been reported to have preemergent crabgrass activity. They reported no beneficial response from the additives but concluded corn gluten hydrolysate may still be beneficial. Earlywine et al. (2010) tested oriental mustard seed meal as a soil treatment to suppress crabgrass germination. Treatments were effective but negatively affected desirable turf species. Mahoney et al. (2014) used liquid carbon dioxide in a study on crabgrass in established turf species and found high usage rates to be effective in controlling juvenile crabgrass plants, with desirable turf species temporarily affected.

Another technique of reducing herbicide usage is through cultural control methods. One of the most studied cultural control methods for crabgrass is mowing. Dernoeden et al. (1993) found a mowing height of $8.8 \mathrm{~cm}$ provided good crabgrass control compared with shorter mowing heights and also provided the best turf quality on one variety of tall fescue. The authors also reported that nitrogen applications helped reduce crabgrass control in plots not treated with herbicides. Similar results have been reported for chewings

\begin{tabular}{llll}
\hline $\begin{array}{l}\text { Units } \\
\begin{array}{l}\text { To convert U.S. to SI, } \\
\text { multiply by }\end{array}\end{array}$ & U.S. unit & SI unit & $\begin{array}{l}\text { To convert SI to U.S., } \\
\text { multiply by }\end{array}$ \\
\hline 0.3048 & $\mathrm{ft}$ & $\mathrm{m}$ & 3.2808 \\
9.3540 & $\mathrm{gal} / \mathrm{acre}$ & $\mathrm{L} \cdot \mathrm{ha}^{-1}$ & 0.1069 \\
2.54 & inch $(\mathrm{es})$ & $\mathrm{cm}$ & 0.3937 \\
1.1209 & $\mathrm{lb} / \mathrm{acre}$ & $\mathrm{kg} \cdot \mathrm{ha}^{-1}$ & 0.8922 \\
0.1198 & $\mathrm{lb} / \mathrm{gal}$ & $\mathrm{kg} \cdot \mathrm{L}^{-1}$ & 8.3454 \\
6.8948 & $\mathrm{psi}$ & $\mathrm{kPa}$ & 0.1450 \\
$\left({ }^{\circ} \mathrm{F}-32\right) \div 1.8$ & ${ }^{\circ} \mathrm{F}$ & ${ }^{\circ} \mathrm{C}$ & $\left({ }^{\circ} \mathrm{C} \times 1.8\right)+32$
\end{tabular}


fescue (Festuca rubra ssp. commutata), kentucky bluegrass (Poa pratensis), perennial ryegrass (Lolium perenne), blends of tall fescue, and a mixture of cool-season turf species (Busey 2003; DeBels et al., 2012; Kowalewski et al., 2010; Voigt et al., 2001). However, Hoyle et al. (2014) reported that increased mowing heights on bermudagrass (Cynodon dactylon) did not decrease crabgrass incidence when no pre- or postemergent herbicides were applied. In a related study, Gannon et al. (2015) reported better crabgrass control on bermudagrass areas treated with preemergent herbicides when mowing heights were higher $(3.8$ vs. $1.5 \mathrm{~cm}$ of cut) in one of their two evaluation years.

While the previous studies conducted on cool-season turfgrasses have shown decreased crabgrass incidence at higher mowing heights, they all used a consistent height of cut for the entire growing season. Also, increased mowing heights typically result in better quality, but lower heights of cut within a species tolerance range can result in increased plant density over higher heights of cut (Turgeon, 2005). Therefore, the first objective of this study was to determine if lower heights of cut during spring and fall for cool-season grasses would increase stand density sufficiently to limit smooth crabgrass encroachment. The second objective was to determine if seasonal changes in mowing heights on tall fescue would allow a reduced rate of prodiamine to provide acceptable smooth crabgrass control.

\section{Materials and methods}

Site Information. The trial was conducted on a mature stand of 'Falcon V' tall fescue grown in a Maury silt loam (fine, mixed, mesic, typic Paleudalf) at the A.J. Powell, Jr. Turfgrass Research Center located on the University of Kentucky Spindletop Research Farm in Fayette County, Kentucky. Within the tall fescue sward, two sites were selected. The first site was the experimental location for Fall 2013 through Summer 2014, whereas the second site was the experimental location for Fall 2014 through Summer 2015. Before initiation of the experiments, the entire tall fescue sward had been maintained at a mowing height of 3.5 inches. This height was maintained until each experiment was initiated. To ensure good crabgrass incidence, both sites were seeded with smooth crabgrass at $15.8 \mathrm{lb} /$ acre on 10 May 2014 and 31 Mar. 2015 for the first and second experiments, respectively. The later seeding date in 2014 was due, in part, to a delay in acquiring the seed from a grass breeder in Kentucky who had collected seed from indigenous populations in the area. Both sites were irrigated to promote seed germination and then as needed to prevent drought stress. Mean soil temperatures for the week that each site was seeded were $17^{\circ} \mathrm{C}$ in 2014 and $10^{\circ} \mathrm{C}$ in 2015.

Treatments AND EXPerimental DESIGN. The experimental design for the trial was a strip-split plot with a whole plot randomized complete block. Whole plots were $10 \times 40 \mathrm{ft}$ and consisted of one of four summer mowing heights $(S)$ which were 1,2 , 3 , and 4 inches. Strip plots were $10 \times$ $10 \mathrm{ft}$ and consisted of one of four fall and spring (FS) mowing heights which were also $1,2,3$, and 4 inches. The split plots were $5 \times 10 \mathrm{ft}$ and included no herbicide application or a low rate of prodiamine applied at $0.34 \mathrm{lb} /$ acre a.i. (Barricade 4FL, 4 lb/gal a.i.; Syngenta Crop Protection, Greensboro, NC). Mowing treatments were initiated in Nov. 2013 and Dec. 2014 at the FS mowing heights for the first and second site, respectively. These treatments were followed the remainder of the growing season in each year, before beginning again in March of the following year. For both sites, spring mowing treatments were followed until June, at which point $S$ mowing treatments were initiated and followed until October for both sites. All treatments for both sites were mowed using a rotary mower (John Deere ZTrak Z925A PRO; Deere \& Co., Moline, IL). Herbicide applications were applied 4 May 2014 and 8 Apr. 2015 for the first and second experiments, respectively. Preemergent herbicide applications were applied using a carbon dioxide boom sprayer equipped with three flat spray nozzles (8004VS; TeeJet Technologies, Wheaton, IL) at a pressure of 30 psi with a carrier rate of $52 \mathrm{gal} /$ acre water.

Response variables for this study included visual estimations of percent crabgrass cover within each plot and stand density of the tall fescue using a $0 \%$ to $100 \%$ rating scale. These ratings were taken toward the end of the growing season for both years of the study. Cover ratings were taken on each split plot while density ratings were taken for each strip plot.

Percent crabgrass and sward density data were analyzed using the general linear model procedure of SAS (version 9.3; SAS Institute., Cary, NC). Based on the distribution of the percent crabgrass cover data values, an arcsine transformation was conducted and means were then separated using a $t$ test $(P \leq 0.05)$; however, the original crabgrass cover means are presented in the results section and tables. Means for the sward density data values were also separated using a $t$ test $(P \leq 0.05)$; but data were not transformed.

\section{Results and discussion}

A significant year effect existed for both cover and density $(P<0.05)$, therefore results by year are reported separately (data not shown). The most likely cause of this difference is that 2014 was a drier year at the research site than 2015 with yearly rainfall totals of 58.2 and 79.6 inches for 2014 and 2015, respectively. From these totals, 16.9 inches of rainfall occurred during the hottest Kentucky months of June, July, and Aug. 2014, whereas 27.2 inches fell during these months in 2015. In addition, the later crabgrass seeding date in 2014 may also have contributed to the cover difference between the 2 years.

Crabgrass Cover and fescue DENSITY IN 2014. For 2014, the effects of FS mowing heights, $S$ mowing heights, and the application of a preemergent herbicide were all significant on crabgrass cover ratings. The interaction of FS heights and $S$ heights was significant but no interaction was detected with the herbicide application. Tall fescue mowed at 3 - and 4-inch heights, continuously or FS and S, had less crabgrass encroachment compared with tall fescue maintained at 1- or 2-inch heights at some point during the year. In addition, all mowing height combinations which included 1 inch at some point during the year had more crabgrass than all combinations which did not include 1 inch. The only exception occurred with tall fescue mowed in FS 
at a height of 2 inches and $S$ at 1 inch was not different compared with tall fescue maintained at 2 inches continuously. Cover ratings for all combinations during this year ranged from $0.0 \%$ to $39.4 \%$ (Table 1 ).

Density ratings for 2014 showed effects of FS heights, $S$ heights, and the interaction of the two mowing regimens were all significant. The combination of a FS height of 4 inches and a $S$ height of 1 inch had the lowest sward density at 4.8 , although this combination was not significantly different from three of the four combinations which included a FS height of 1 inch. In addition, all treatment combinations which included the FS height of 1 inch resulted in lower density compared with the majority of other mowing treatments. Outside of these combinations, most other treatments were not different from each other with sward density ranging from 4.8 to 7.3 (Table 2).

Crabgrass Cover In 2015. Similar to 2014, the effects of FS mowing heights and $S$ mowing heights, and the application of a preemergent herbicide affected crabgrass coverage. Mowing continuously at 4 -inch height resulted in less crabgrass cover compared with all other mowing regimens with the exception of the two combinations of the 3 - and 4 -inch heights at $0.1 \%$ and below. All four combinations including $S$ mowing height at 1 inch had the highest crabgrass cover ratings at $9.1 \%$ to $18.1 \%$; however, these treatments were not significantly different from several other mowing height combinations. Crabgrass cover across all mowing height treatments ranged from $0.0 \%$ to $18.1 \%$ in 2015 .

In 2015 , there were also interactions between the mowing height treatments and the herbicide application which were not evident in 2014. Overall in 2015, every treatment combination that included the preemergent herbicide application tended to have less crabgrass than the treatment combinations that did not include the preemergent herbicide. The exceptions to this were the combinations that did not have the herbicide application but did have the 4 -inch height alone for the year or in a combination with the 3 -inch height. These combinations were not significantly different from most of the combinations that did receive the herbicide application, and in some cases

Table 1. Mean percent crabgrass cover ratings across all fall/spring and summer mowing height combinations in 2014 and 2015. Fall/spring mowing treatments were initiated in Nov. 2014 and Dec. 2015. These were followed for the remainder of the growing season each year, and from March to June the next year, at which point summer mowing treatments were initiated and followed through October. Percent cover means were adjusted using an arcsine transformation and then separated using a $t$ test $(P \leq 0.05)$; however, original means are presented.

\begin{tabular}{lccc}
\hline $\begin{array}{l}\text { Fall/spring } \\
\text { ht (inches) }\end{array}$ & $\begin{array}{c}\text { Summer } \\
\text { ht (inches) }\end{array}$ & $\begin{array}{c}\mathbf{2 0 1 4} \\
\text { cover (\%) }\end{array}$ & $\begin{array}{c}\mathbf{2 0 1 5} \\
\text { cover (\%) }\end{array}$ \\
\hline 4 & 4 & $0.0 \mathrm{e}$ & $0.0 \mathrm{i}$ \\
4 & 3 & $0.1 \mathrm{e}$ & $0.1 \mathrm{hi}$ \\
4 & 2 & $7.9 \mathrm{~d}$ & $3.3 \mathrm{defg}$ \\
4 & 1 & $35.0 \mathrm{ab}$ & $12.0 \mathrm{ab}$ \\
3 & 4 & $0.3 \mathrm{e}$ & $0.1 \mathrm{hi}$ \\
3 & 3 & $0.9 \mathrm{e}$ & $0.9 \mathrm{gh}$ \\
3 & 2 & $8.4 \mathrm{~d}$ & $3.0 \mathrm{efg}$ \\
3 & 1 & $24.9 \mathrm{~b}$ & $18.1 \mathrm{a}$ \\
2 & 4 & $6.1 \mathrm{~d}$ & $1.7 \mathrm{fg}$ \\
2 & 3 & $8.9 \mathrm{~d}$ & $3.2 \mathrm{defg}$ \\
2 & 2 & $13.6 \mathrm{~cd}$ & $3.6 \mathrm{def}$ \\
2 & 1 & $23.4 \mathrm{bc}$ & $10.7 \mathrm{~b}$ \\
1 & 4 & $39.4 \mathrm{a}$ & $5.2 \mathrm{cde}$ \\
1 & 3 & $29.4 \mathrm{ab}$ & $5.6 \mathrm{cde}$ \\
1 & 2 & $31.3 \mathrm{ab}$ & $7.1 \mathrm{bcd}$ \\
1 & 1 & $33.2 \mathrm{ab}$ & $9.1 \mathrm{bc}$ \\
\hline${ }^{\mathrm{z}} 1$ inch $=2.54 \mathrm{~cm}$. & &
\end{tabular}

Table 2. Mean tall fescue density ratings $(1=$ worst, $9=$ best $)$ across all fall $/$ spring and summer mowing height combinations in 2014 and 2015. Fall/spring mowing treatments were initiated in Nov. 2014 and Dec. 2015. These were followed for the remainder of the growing season each year, and from March to June the next year, at which point summer mowing treatments were initiated and followed through October. Density means were separated using a $t \operatorname{test}(P \leq 0.05)$.

\begin{tabular}{lccc}
\hline $\begin{array}{l}\text { Fall/spring } \\
\text { ht (inches) }\end{array}$ & $\begin{array}{c}\text { Summer } \\
\text { ht (inches) }\end{array}$ & $\begin{array}{c}\text { 2014 density } \\
(\mathbf{1}-9 \text { scale })\end{array}$ & $\begin{array}{c}\text { 2015 density } \\
(\mathbf{1 - 9} \text { scale) }\end{array}$ \\
\hline 4 & 4 & $7.0 \mathrm{ab}^{\mathrm{y}}$ & $6.8^{\mathrm{x}}$ \\
4 & 3 & $6.8 \mathrm{ab}$ & 7.0 \\
4 & 2 & $7.0 \mathrm{ab}$ & 7.3 \\
4 & 1 & $4.75 \mathrm{f}$ & 6.5 \\
3 & 4 & $7.0 \mathrm{ab}$ & 7.3 \\
3 & 3 & $7.0 \mathrm{ab}$ & 6.8 \\
3 & 2 & $7.3 \mathrm{a}$ & 7.3 \\
3 & 1 & $6.3 \mathrm{bcd}$ & 6.5 \\
2 & 4 & $7.0 \mathrm{ab}$ & 7.0 \\
2 & 3 & $6.5 \mathrm{abc}$ & 6.8 \\
2 & 2 & $7.3 \mathrm{a}$ & 7.0 \\
2 & 1 & $6.8 \mathrm{ab}$ & 7.0 \\
1 & 4 & $5.8 \mathrm{cde}$ & 6.0 \\
1 & 3 & $5.3 \mathrm{ef}$ & 7.0 \\
1 & 2 & $5.3 \mathrm{ef}$ & 6.8 \\
1 & 1 & $5.5 \mathrm{def}$ & 6.5 \\
\hline
\end{tabular}

${ }^{\mathrm{z}} 1$ inch $=2.54 \mathrm{~cm}$.

${ }^{\mathrm{y}}$ Treatments with the same letter following ratings were not significantly different at $P=0.05$.

${ }^{\mathrm{x}}$ Mean separations are not presented for 2015 due to a lack of significant effects in that year.

also had less crabgrass than many of those treatment combinations as well. Another exception was the treatment combination of a 3 -inch FS height, a l-inch $S$ height, and the herbicide application which had more crabgrass than most other treatments that also received the herbicide application. When no herbicide was applied, the treatments that included the 1 -inch 
$S$ height, and the treatment which had the 1 -inch FS and 2 -inch $S$ height, had significantly more crabgrass than the majority of all other treatment combinations, with ratings ranging from $19.2 \%$ to $32.4 \%$ (Table 3 ).

No effects were significant for density ratings in 2015 , however, the $S$ mowing treatments were close to being significant at $P=0.527$. The lack of significant effects on density in 2015 would help to support the overall significant year difference since some of these effects were significant in 2014.

When examining data from each year, mowing heights of 3 or 4 inches continuously throughout the year reduced smooth crabgrass encroachment in tall fescue. The results of this study support the findings from past mowing height regimens conducted on various cool-season grasses without seasonal adjustments (Busey 2003; DeBels et al., 2012; Dernoeden et al., 1993; Kowalewski et al., 2010; Voigt et al., 2001). In this study, there were no significant differences between seasonal adjustments of only the 3 - and 4 -inch heights, with the exception of the treatment using only the 3 -inch height for the year having more

Table 3. Mean percent crabgrass cover ratings across all fall/spring mowing height, summer mowing height, and herbicide combinations in $2015^{\mathrm{z}}$. Fall/ spring mowing treatments were initiated in Nov. of 2014 and Dec. of 2015. These were followed for the remainder of the growing season each year, and from March to June the next year, at which point summer mowing treatments were initiated and followed through October. Herbicide application consisted of a low rate of prodiamine $\left[0.34 \mathrm{lb} /\right.$ acre $\left(0.381 \mathrm{~kg} \cdot \mathrm{ha}^{-1}\right)$ a.i. $]$ applied on $8 \mathrm{Apr}$. 2015. Percent cover means were adjusted using an arcsine transformation and then separated using a $t$ test $(P \leq 0.05)$; however, original means are presented.

\begin{tabular}{|c|c|c|c|}
\hline $\begin{array}{l}\text { Fall/spring } \\
\text { ht (inches) }\end{array}$ & $\begin{array}{c}\text { Summer } \\
\text { ht (inches) }\end{array}$ & $\begin{array}{c}\text { Herbicide } \\
\text { application }\end{array}$ & $\begin{array}{c}2015 \\
\text { cover }(\%) \\
\end{array}$ \\
\hline 4 & 4 & Yes & $0.0 \mathrm{l}^{\mathrm{x}}$ \\
\hline 4 & 4 & No & 0.01 \\
\hline 4 & 3 & Yes & 0.01 \\
\hline 4 & 3 & No & 0.11 \\
\hline 4 & 2 & Yes & 0.11 \\
\hline 4 & 2 & No & $10.6 \mathrm{defg}$ \\
\hline 4 & 1 & Yes & 2.9 hijk \\
\hline 4 & 1 & No & $26.1 \mathrm{ab}$ \\
\hline 3 & 4 & Yes & 0.01 \\
\hline 3 & 4 & No & $0.5 \mathrm{kl}$ \\
\hline 3 & 3 & Yes & 0.01 \\
\hline 3 & 3 & No & 3.7 hij \\
\hline 3 & 2 & Yes & 0.11 \\
\hline 3 & 2 & No & $9.6 \mathrm{efg}$ \\
\hline 3 & 1 & Yes & $7.3 \mathrm{fgh}$ \\
\hline 3 & 1 & No & $32.4 \mathrm{a}$ \\
\hline 2 & 4 & Yes & 0.11 \\
\hline 2 & 4 & No & $5.0 \mathrm{ghi}$ \\
\hline 2 & 3 & Yes & $0.8 \mathrm{jkl}$ \\
\hline 2 & 3 & No & 7.1 fghi \\
\hline 2 & 2 & Yes & 0.11 \\
\hline 2 & 2 & No & $11.5 \mathrm{cdef}$ \\
\hline 2 & 1 & Yes & 3.7 hij \\
\hline 2 & 1 & No & $20.7 \mathrm{~b}$ \\
\hline 1 & 4 & Yes & 0.11 \\
\hline 1 & 4 & No & 17.0 bcde \\
\hline 1 & 3 & Yes & 0.11 \\
\hline 1 & 3 & No & $18.3 \mathrm{bcd}$ \\
\hline 1 & 2 & Yes & 0.11 \\
\hline 1 & 2 & No & $23.4 \mathrm{ab}$ \\
\hline 1 & 1 & Yes & $2.5 \mathrm{ijk}$ \\
\hline 1 & 1 & No & $19.2 \mathrm{bc}$ \\
\hline
\end{tabular}

${ }^{\mathrm{z}} 2014$ ratings were excluded due to differences in that year not being significant $(P>0.05)$.

${ }^{y} 1$ inch $=2.54 \mathrm{~cm}$

${ }^{x}$ Treatments with the same letter following ratings were not significantly different at $P=0.05$.

crabgrass in 2015 compared with the treatment following a continuous 4 -inch mowing regimen.

It was hypothesized seasonal adjustments involving high summer heights of cut and low FS mowing heights would result in the least crabgrass encroachment. This was supported with the idea that lower, tolerable mowing heights within a species could increase stand density (Turgeon, 2005). The results of this study clearly showed seasonal mowing height adjustments had little to no effect on density in 2015 but did affect density in 2014. Overall, treatment combinations including the l-inch height at some point during the year had the lowest density ratings which could be explained by that height of cut being unacceptable for tall fescue. Combinations including the 2 - and 3 -inch heights alone or combined did result in numerically higher density values than the use of 4 -inch height alone across a year, however, this difference was not significant. Based on this, the use of lower heights did improve density a small amount but seasonal adjustments had no effect on density when the 1 -inch height was not used.

The reduced density values when the 1 -inch height was used, along with the lack of improvement to density when the 2- and 3 -inch heights were used during the year may explain why these combinations had more crabgrass than combinations using only the 3-and 4-inch heights. When considering only the 3 - and 4-inch heights, it is important to consider which height would be acceptable for the average homeowner. A mowing height of 4 inches throughout the entire year did have the lowest crabgrass amounts in both years but consistent use of this height may be perceived as unacceptable by many homeowners. Ray et al. (2007) reported that when just comparing a 2- vs. 3-inch height of cut across several tall fescue cultivars, the 2 -inch height overall had better quality across the year. A consistent mowing height of 4 inches would most likely result in even more reduced quality over the 3-inch height, and therefore be considered undesirable for many homeowners. Since the use of the 3 -inch height for part or all of the year was not significantly different from the 4-inch height alone, (apart 
from the 2015 exception of the 3 inch height alone) it can be concluded that using the 3 -inch height may be just as good in reducing smooth crabgrass incidence, and more acceptable to homeowners.

The second part of this study examined if season mowing height changes could allow a reduced rate of prodiamine to sufficiently control crabgrass. In 2014, no significant herbicide interactions were detected which may in part be due to the drier conditions in that year. From the herbicide label, it is clear that water is a key component in good herbicide efficacy and while the site was irrigated, the drier conditions may have affected the herbicide in that year (Syngenta Crop Protection, 2012). The significant interactions in 2015, however, suggest that as long as a summer height of 1 inch is not used, which would severely stress tall fescue, then the $0.34 \mathrm{lb} /$ acre a.i. rate of prodiamine is sufficient to keep smooth crabgrass severity at $0.8 \%$ or below, which should be considered acceptable for most homeowners. Based on this, the mowing height of tall fescue used throughout a year does not greatly matter for crabgrass incidence when at least a low rate of prodiamine is applied and a mowing height greater than 1 inch is used. Also, in this study when a 4 -inch mowing height was used alone or combined with a 3 -inch height during 2015, acceptable crabgrass reduction was obtained without using any preemergent herbicide.

When examining the results of this study, there is no need to make seasonal mowing height adjustments to tall fescue or to apply a preemergent herbicide to tall fescue to reduce crabgrass incidence when heights of cut $\geq 3$-inch are being followed and there is good stand density. This study also suggests that if lower mowing heights are used or desired and weed pressure is expected, then a low rate of prodiamine may sufficiently control smooth crabgrass as long as mowing heights are greater than 1 inch.

\section{Literature cited}

BASF Corporation. 2012. Drive XLR8 label. BASF Corp., Research Triangle Park, NC.

Bayer Environmental Science. 2011. Acclaim Extra label. Bayer Environmental Science, Research Triangle Park, NC.

Beck, L.L., A.J. Patton, Q.D. Law, D.V. Weisenberger, J.T. Brosnan, J.J. Vargas Almodovar, G.K. Breeden, and D.A. Kopsell. 2015. Mesotrione activity on crabgrass (Digitaria spp.) as influenced by nitrogen fertilization rate, source, and timing. Weed Technol. 29:263-273.

Busey, P. 2003. Cultural management of weeds in turfgrass: A review. Crop Sci. 43:1899-1911.

DeBels, B.T., S.E. Griffith, W.C. Kreuser, E.S. Melby, and D.J. Soldat. 2012. Evaluation of mowing height and fertilizer application rate on quality and weed abundance of five home lawn grasses. Weed Technol. 26:826-831.

Dernoeden, P.H., M.J. Carroll, and J.M. Krouse. 1993. Weed management and tall fescue quality as influenced by mowing, nitrogen, and herbicides. Crop Sci. 33:10551061 .

Dernoeden, P.H. 2001. Reduced herbicide rates for smooth crabgrass control in the mid-Atlantic region. Intl. Turfgrass Soc. Res. J. 9:1005-1008.

Derr, J.F. 2004. Prodiamine timing for large crabgrass and japanese stiltgrass control. North Central Weed Sci. Proc. 59:110 (abstr.).

Earlywine, D.T., R.J. Smeda, T.C. Teuton, C.E. Sams, and X. Xiong. 2010. Evaluation of oriental mustard (Brassica juncea) seed meal for weed suppression in turf. Weed Technol. 24:440-445.

Environmental Protection Agency. 2016. Monosodium methanearsonate (MSMA), an organic aresenical. 16 Mar. 2016 . <https://www.epa.gov/ ingredients-used-pesticide-products / monosodium-methanearsonate-msmaorganic-arsenical>.
Gannon, T.W., M.D. Jeffries, J.T. Brosnan, G.K. Breeden, K.A. Tucker, and G.M. Henry. 2015. Preemergence herbicide efficacy for crabgrass (Digitaria spp.) control in common bermudagrass managed under different mowing heights. HortScience 50:546-550.

Hoyle, J.A., T.W. Gannon, and F.H. Yelverton. 2014. Effect of common bermudagrass mowing height on large crabgrass incidence. Appl. Turfgrass Sci. doi: 10.2134/ATS-2013-0065-BR.

Kowalewski, A.R., R.N. Calhoun, A.D. Hathaway, and J.N. Rogers. III. 2010. Using cultural practices and leaf mulch to control weeds in established turfgrass. Appl. Turfgrass Sci. doi: 10.1094/ATS2010-0416-01-RS

Mahoney, D.J., M.D. Jeffries, and T.W. Gannon. 2014. Weed control with liquid carbon dioxide in established turfgrass. Weed Technol. 28:560-568.

McCarty, L.B., J.W. Everest, D.W. Hall, T.R. Murphy, and F. Yelverton. 2001. Color atlas of turfgrass weeds. Ann Arbor Press, Chelsea, MI.

McDade, M.C. and N.E. Christians. 2001. Corn gluten hydrolysate for crabgrass (Digitaria spp.) control in turf. Intl. Turfgrass Soc. Res. J. 9:1026-1029.

Ray, W.F., G.A. Picchioni, D.M. VanLeeuwen, and R.M. Goss. 2007. First-year response of turf-type tall fescue cultivars to different fertilization rates and mowing heights in semiarid conditions. HortTechnology 17:353-357.

Syngenta Crop Protection. 2012. Barricade 4FL label. Syngenta Crop Protection, Greensboro, NC.

Syngenta Crop Protection. 2014. Fusillade II turf and ornamental herbicide label. Syngenta Crop Protection, Greensboro, NC.

Turgeon, A.J. 2005. Turfgrass management. 7th ed. Pearson Prentice Hall, Upper Saddle River, NJ.

Voigt, T.B., T.W. Fermanian, and J.E. Haley. 2001. Influence of mowing and nitrogen fertility on tall fescue turf. Intl. Turfgrass Soc. Res. J. 9:953-956. 